\title{
THE EFFECTIVENESS OF INTERNAL CONTROLS AND UNDERSTANDING OF ACCOUNTING INFORMATION SYSTEMS ON THE QUALITY OF FINANCIAL STATEMENTS
}

\author{
Virginia Comely Wakulu \\ Faculty of Economics and Business Universitas Klabat \\ virginiacwakulu@gmail.com \\ Novie P. Sibilang \\ Faculty of Economics and Business Universitas Klabat \\ novie@unklab.ac.id
}

\begin{abstract}
This study aims to determine and analyze the effect of the internal controls effectiveness and the accounting information systems understanding on the quality of financial statements of financial institutions and regional assets in North Sulawesi province. The independent variable in this study is the internal control effectiveness and the accounting information systems understanding, while the dependent variable in this study is the quality of financial reports. The method used in this research is descriptive quantitative method. Respondents whofilled out the questionnaire were divided into two groups, namely Regional Asset Finance Agency employees who prepared of financial reports answering questions related to the internal control effectiveness and the accounting information system understanding, and SKPD employees who users of financial reports were answering questions related to the quality of financial reports. The number of respondents from the two groups were 53 people. The results showed that the effectiveness of internal control and the understanding of the accounting information system had a significant effect on the quality of financial reports with the adjusted $R^{2}$ value of 0.570 .
\end{abstract}

Keywords: Accounting information system, internal control, quality of financial statement

\section{KEEFEKTIFAN PENGENDALIAN INTERN DAN PEMAHAMAN SISTEM INFORMASI AKUNTANSI TERHADAP KUALITAS LAPORAN KEUANGAN}

\begin{abstract}
Abstrak
Penelitian ini bertujuan untuk mengetahui dan menganalisa pengaruh keefektifan pengendalian intern dan pemahaman sistem informasi akuntansi terhadap kualitas laporan keuangan Badan Keuangan dan Aset Daerah Provinsi Sulawesi Utara. Varibel bebas pada penelitian ini ialah keefektifan pengendalian intern dan pemahaman sistem informasi akuntansi, sedangkan variabel terikat pada penelitian ini ialah kualitas laporan keuangan. Metode yang digunakan dalam
\end{abstract}


penelitian ini deskriptif kuantitatif. Responden kuesioner penelitian terbagi atas dua kelompok, yaitu pegawai Badan Keuangan Aset Daerah yang merupakan pembuat laporan keuangan menjawab pertanyaan terkait keefektifan pengendalian intern dan pemahaman sisteminformasi akuntansi dan pegawai SKPD yang merupakan pengguna laporan keuangan menjawab pertanyaan terkait kualitas laporan keuangan. Jumlah responden dari kedua kelompok sebanyak 53 orang. Hasil penelitian menunjukkan bahwa keefektifan pengendalian intern dan pemahaman sistem informasi akuntansi memiliki pengaruh signifikan terhadap kualitas laporan keuangan dengan nilai adjusted $R^{2}$ sebesar 0,570 .

\section{Kata kunci: kualitas laporan keuangan, sistem informasi akuntansi, sistem pengendalian internal}

\section{Pendahuluan}

Di era globalisasi ini, masih terdapat banyak kesalahan dalam penyajian data laporan keuangan dan terjadinya penyimpangan-penyimpangan serta kasus kecurangan yang ditemukan oleh Badan Pemeriksa keuangan (BPK) ketika melaksanakan audit laporan keuangan pemerintah.Kasus kecurangan bukan hanya terjadi pada sektor swasta tetapi sering terjadi pada sektor pemerintahan. Hal tersebut dapat dibuktikan dari hasil pemeriksaan Badan Pemeriksa Keuangan (BPK) terhadap laporan keuangan pemerintah pusat dan pemerintah daerah tahun 2013 semester 1 yang menyebabkan potensi kerugian negara mencapai Rp 56,98 triliun, kemudian Pemeriksaan BPK mengenai laporan keuangan Badan X1 tahun 2013-2015 menemukan adanya kelemahan padasistem pengendalian intern. Temuan-temuan tersebut menandakan bahwa dalam pengelolaan keuangannya belum menyajikan informasi keuangan yang handal dan masih memiliki potensi terhadap kecurangan, untuk itu dibutuhkan usaha pencegahan.

Kondisi-kondisi tersebut mendorong pemerintah pusat serta pemerintah daerah untuk bertanggung jawab dalam mengimplementasikan akuntabilitas publik. Salah satu wujud pertanggungjawaban dalam menyelenggarakan pemerintahan terdapat dalam Undang-undangNomor 17 Tahun 2003 mengenai Keuangan Negara serta Undang-undang Nomor 32 Tahun 2004mengenai Pemerintah Daerah, yang merupakan Laporan Keuangan. Dalam penyajian laporan keuangan ada kemungkinan terdapat kesalahan bahkan penyimpangan yang dapat merugikan masyarakat sebagai pemangku kepentingan (stakeholder). Untuk itu perlu dilakukan tindakan pencegahaan pada sektor pemerintahan. Tindakan pencegahan dapat dimulai dari memperhatikan keefektifan pengendalian internal, pemahaman sistem informasi akuntansi dari para pegawai yangada dan yang bertanggung jawab pada masing-masing bidang pemerintahan.

Menurut Wilopo (2006) pengendalian intern yang efektif akan mengurangi potensi kecurangan dalam organisasi. Sawyre (2006) menyimpulkan adanya pengendalian intern yang baik, maka dapat dikatakan pemerintahan tersebut mempunyai efektivitas dan efisiensi dalam operasional, mempunyai laporan keuangan yang handal dan memberikan jaminan telah mengikutiaturan dan ketentuan hukum.

Selain pengendalian intern, sistem informasi akuntansi yang menciptakan informasi yang berkualitas dibutuhkan oleh pihak pemerintah dalam menangani kegiatan operasionalnya. Informasi akuntansi menjadi informasi yang bermanfaat untuk pengambilan keputusan. Sebelum menerapkan sistem informasi yang andal dan berkualitas, para pegawai yang ada dalam pemerintah harus memahami dengan benar sistem informasi suatu pemerintahan. Lebih lengkapnya lagi sistem informasi akuntansi keuangan daerah menurut Yuliani (2010) merupakan suatu sistem pengelompokkan, penggolongan, pencatatan dan menjalankan aktivitas keuangan pemerintah daerah 
kedalam sebuah laporan keuangan menjadi suatu informasi yang dapat dipakaioleh pihak tertentu saat pengambilan keputusan. Dapat dikatakan, untuk dapat menyajikan laporan keuangan yang berkualitas, dibutuhkan pemahaman sistem informasi akuntansi yang baik dan sistem pengendalian intern yang efektif dalam suatu perusahaan (Octavianty, 2019).

Laporan keuangan adalah hal utama yang menjadi gambaran pokok dalam pengambilan keputusan (Ikatan Akuntan Indonesia, 2015). Kualitas dari laporan keuangan mempengaruhi akuntabilitas, laporan keuangan yang baik dapat mempertanggung jawabkan seluruh informasi yang terkandung dalam laporan keuangan tersebut. Laporan keuangan dikatakan berkualitas jika menyajikan data-data sesuai dengan kriteria Standar Akuntansi Pemerintah, kepatuhan terhadap peraturan perundang-undangan dan adanya pengendalian intern yang efektif. Kualitas laporan keuangan dapat dilihat dari karakteristik kualitatif laporan keuangan, karakteristik kualitatif yang terdapat dalam Kerangka Konseptual Akuntansi Pemerintahan tentang Standar Akuntansi Pemerintahan mengacuh pada Peraturan Pemerintah No. 71 Tahun 2010 yakni relevan, andal, dapat dibandingkan serta dapat dipahami dan BPK RI bertanggung jawab dalam pemeriksaan laporan keuangan berdasarkan UU Nomor 15 Tahun 2004 pasal 12 (Badan Pemeriksa Keuangan Republik Indonesia, 2004).

Laporan keuangan pemerintah provinsi Sulawesi Utara yang dinyatakan oleh BPKP dalam tiga tahun terakhir telah menyajikan informasi anggaran dan posisi keuangan secara layak dan berakuntabilitas sesuai dengan standard akuntansi pemerintahan, yang telah disusun berdasarkan sistem pengendalian intern yang memadai (Badan Pengawasan Keuangan dan Pembangunan, 2017). Dengan demikian peneliti ingin meneliti apakah keefektifan pengendalian intern dan pemahaman sistem informasi akuntansi dapat meningkatkan kualitas laporan keuangan institusi sektor publik khususnya daerah pemerintahan Sulawesi Utara sehingga akan menjadi masukkan kepada pihak terkait.

\section{Telaah Pustaka dan Pengembangan Hipotesis}

\section{Keefektifan Pengendalian Intern}

Berdasarkan peraturan pemerintah RI No. 60 Tahun 2008, sistem pengendalian intern merupakan langkah-langkah yang terstruktur dan kegiatan yang dilakukan oleh pihak perusahaan baik pimpinan maupun seluruh pegawai untuk menyatakan kegiatan dalam pemerintahan berjalan dengan efektif, adanya laporan yang andal, keamanan aset dalam perusahaan serta kebijakan dan peraturan dalam perusahaan dipatuhi, oleh karena hal-hal tersebut dapat dikatakan tujuan organisasi tercapai. Hariadi (2010) mengemukakan sistem pengendalian internal Pemerintah diatur dalam Peraturan Pemerintah RI No. 60 tahun 2008.

Walaupun tidak bertujuan mencari laba, organisasi pemerintahan tetap memerlukan sistem pengendalian intern yang dapat mengatur secara efektif dan efisien dikarenakan tanggung jawab yang tinggi yaitu kepada masyarakat. Untuk pernyataan mengenai sist (Peraturan Pemerintah Republik Indonesia nomor 71 tahun 2010, 2010) (Ikatan Akuntansi Indonesia, 2009)em pengendalian intern dibagian pemerintahan terdapat dalam peraturan pemerintah RI no. 60 tahun 2008 (Hariadi, Pengelolaan keuangan daerah, 2010). Tujuan dari Sistem Pengendalian Intern Pemerintah menurut Peraturan Pemerintah Nomor 60 Tahun 2008 pasal 2 (ayat 3), antara lain, meyakinkan pencapaian tujuan pemerintah, adanya sistem pelaporan yang andal, penjagaan yang ketat terhadap aktiva negara dan menaati peraturan yang diterapkan. 


\section{H1: Keefektifan Pengendalian Intern berpengaruh signifikan terhadap kualitas laporan Keuangan}

\section{Sistem Informasi Akuntansi}

Sistem informasi akuntansi menurut Baridwan adalah aktivitas mengumpulkan, mengklarifikasikan dan menggabungkan informasi keuangan bagi pihak eksternal untuk pengambilan keputusan. Terdapat 3 tujuan sistem informasi akuntansi menurut Marshal B. Romney dan Paul J. Steinbert (2005, 3) yaitu mengumpul aktivitas, sumberdaya, mengarsip data perusahaan, kedua mengubah data menjadi info berharga untuk organisasi dan yang terakhir mengamankan aktiva dan data perusahaan melalui pengendalian yang sesuai.

Informasi akuntansi menjadi informasi yang bermanfaat untuk pengambilan keputusan, sebelum menerapkan sistem informasi yang andal dan berkualitas, para pegawai yang ada dalam pemerintah harus memahami dengan benar sistem informasi suatu pemerintahan. Sistem informasi akuntansi merupakan suatu bentuk sistem informasi untuk mempersiapkan informasi bagi mereka yang bertanggung jawab pada pengawasan, memperbaiki informasi dan pengendalian serta pengecekan internal dengan tujuan mendorong seoptimal mungkin agar dapat menghasilkan berbagai informasi akuntansi yang berkualitas yaitu informasi yang tepat waktu, relevan, akurat (dapat dipercaya) dan lengkap yang secara keseluruhan informasi akuntansi tersebut mengandungarti dan berguna (Azhar \& Susanto, 2001).

\section{H2: Pemahaman Sistem Informasi Akuntansi berpengaruh signifikan terhadap kualitas laporan keuangan}

\section{Kualitas Laporan Keuangan}

Menurut kerangka konseptual Akuntansi Pemerintahan mengenai karakteristik kualitatif, laporan keuangan yang berkualitas adalah laporan keuangan yang memenuhi syarat karakteristik kualitatif sebuah laporan keuangan, antara lain relevan, andal, dapat dibandingkan dan dapat dipahami. Undang-undang No.17 tahun 2003 mengisyaratkan bahwa laporan keuangan laporan pertanggungjawaban pemerintah harus diaudit oleh Badan pemeriksa keuangan (Kementerian Keuangan, 2003). Opini BPK dapat berupa WTP (wajar tanpa pengecualian), WDP (wajar dengan pengecualian), TMP (tidak memberikan pendapat), TW (tidak wajar) (Juwita, 2013). Berdasarkan lampiran tentang kerangka konseptual akuntansi pemerintahan pada PP no 71 tahun 2010 dinyatakan terdapat 8 Prinsip akuntansi dan pelaporan keuangan, yaitu:nilai historis, periodisitas, penyajian wajar, konsistensi, pengungkapan lengkap, basis akuntansi dan realisasi. Sesuai dengankomponenkomponen pertanyaan pada kuesioner yang diisi oleh responden, laporan keuangan dapat dikatakan telah berkualitas jika laporan keuangan mengandung informasi yang memungkinkan pengguna untuk mengoreksi ekpektasi masa lalu, laporan keuangan berisi informasi yang membantu pengguna laporan untuk memprediksi masa yang akan datang berdasarkan hasil masa lalu dan kejadian masa kini, informasi yang disajikan tepat waktu, serta menyajikan secara lengkap informasi-informasi laporan keuangan.

\section{Metedologi Penelitian}

Desain penelitian ini menggunakan metode deskriptif kuantitatif menggunakan data yang 
diperoleh dari sampel populasi penelitian dianalisis sesuai dengan metode statistik yang digunakan. Metode ini dipilih karena penulis ingin memprediksi suatu korelasi antara satu variabeldengan variabel lain dilihat dari beberapa fenomena yang telah terjadi. Dalam hal ini mengetahui dan menganalisa apakah keefektifan pengendalian intern dan pemahaman sistem informasi akuntansi berpengaruh pada kualitas laporan keuangan Badan Keuangan dan Aset Daerah ProvinsiSulawesi Utara.

\section{Populasi dan Sampel Penelitian}

Populasi yang dipakai adalah pegawai yang berada di kantor Gubernur provinsi Sulawesi Utara sedangkan sampel pada penelitian ini adalah karyawan Badan Keuangan Aset Daerah dan Satuan Kerja Perangkat Daerah di kantor Gubernur Provinsi Sulawesi Utara sebanyak 53 orang. Pengambilan sampel pada penelitian ini adalah purposive sampling, yaitu sampel yang di ambil didasarkan pada pertimbangan tujuan dan kegunaan tertentu. Peneliti menentukan kriteria dalam pemilihan sampel penelitian yaitu pegawai yang bekerja terkait dengan bagian keuangan kantor Badan Keuangan Aset Daerah dan SKPD Provinsi Sulawesi Utara adalah pegawai negeri sipil.

Untuk kuesioner mengenai kualitas laporan keuangan (Variabel Y) diisi oleh pengguna laporan keuangan yakni SKPD (Satuan Kerja Perangkat Daerah), sedangkan untuk kuesioner keefektifan pengendalian intern (X1) dan pemahaman sistem informasi akuntansi (X2) diisi oleh pegawai yang berada dibidang akuntansi sebagai penyedia laporan keuangan perusahaan pada Badan Keuangan dan Aset Daerah Provinsi Sulawesi Utara. Kuesioner yang digunakan diadopsi dari penelitian yang sudah dilakukan sebelumnya oleh Darmawan (2018), Saipullah (2017) dan Esya (2008) tetapi pertanyaan yang diambil hanya terbatas pada variabel yang diperlukan pada penelitian ini.

Persamaan yang dipakai adalah model regresi linear berganda yaitu :

Keterangan :

$$
Y=a+\beta_{1} x_{1}+\beta_{2} x_{2}+\varepsilon
$$

$\mathrm{Y}$

$a$

$\beta_{1} \beta_{2}$

$x_{1} \& x_{2}$

$\varepsilon$

\section{Uji Validitas}

Sugiyono (2012) menyatakan validitas adalah derajat akurasi antara data yang terdapatpada objek penelitian dengan data yang dapat dilaporkan dari peneliti. Kuesioner itu nantinya akan dikatakan valid jika pertanyaan-pertanyaan dalam kuesioner dapat memaparkan sesuatu yang nantinya akan diukur melalui kuesioner tersebut. Pada penelitian ini, setiap pertanyaan dibandingkan dengan $r$ hitung dan $r$ tabel. Apabila $r$ hitung $>r$ tabel, maka artinya ada korelasi antar variabel yang dihubungkan atau dapat dikatakan data tersebut valid, namun jika $r$ hitung <dari $r$ tabel maka artinya tidak ada korelasi antar variabel yang dihubungkan atau data yang dipakai pada penelitian ini adalah tidak valid dan uji valid dilakukan berdasarkan Pearson Product Moment dengan nilai r tabel 0,279.

Untuk hasil dalam penelitian ini setelah dilakukan uji valid, semua pertanyaan padamasing-
: koefisien konstanta

: koefisiean regresi

: Keefektifan Pengendalian Intern \& Pemahaman SIA

: error 
masing variabel memiliki nilai $r$ hitung $>\mathrm{r}$ tabel, maka dapat disimpulan semua pertanyaan pada penelitian ini memiliki korelasi antar variabel atau semua pertanyaan dinyatakan valid.

\section{Uji Reliabilitas}

Menurut Groulund dan Linn (1990) reliabilitas merupakan akurasi hasil yang didapatkan dari kegiatan pengukuran. Reliabilitas juga dapat dikategorikan sebagai alat ukur yang dapat digunakan untuk mengukur suatu kuesioner yang merupakan sebuah indikator dari suatu variabelpenelitian.

Pada Penelitian ini, menggunakan Alpha Cronbach dengan ketentuan Jika nilai Alpha Cronbach > 0,60 maka variabel tersebut dinyatakan reliable. Hasil uji reliabilitas pada penelitian ini menunjukan bahwa semua variabel yang terdapat pada penelitian ini dinyatakan reliable atau dapat dipercaya. karena semua nilai alpha cronbach > 0,60, dapat dilihat pada tabel berikut ini :

Tabel 1

\section{Hasil Uji Reabilitas}

\begin{tabular}{lcc}
\hline Variabel & Cronbach's Alpha & N of Items \\
\hline Pengendalian Intern & .903 & 16 \\
Pemahaman SIA & .901 & 14 \\
Kualitas Laporan Keuangan & .887 & 14 \\
\hline Sumber : Pengolahan Data SPSSUji Normalitas &
\end{tabular}

Table 2

Hasil uji normalitas

Unstandardized Residual

Kolmogrov- Smirnov Z $\quad 0.649$

Asymp. Sig. (2-tailed) 0.793

Sumber: Pengolahan Data SPSS

Pada tabel 2 dijelaskan bahwa hasil nilai signifikansi sampel penelitian ini adalah 0,793 atau lebih besar dari 0,05 maka dapat disimpulkan bahwa variabel pada penelitian ini terdistribusisecara normal.

Uji Multikolinearitas

Table 3

Hasil Uji Multikolineritas

\begin{tabular}{lcc}
\hline Variabel & Collinearity Tolerance & Statistic VIF \\
Pengendalian Intern & .712 & 1.404 \\
\hline Pemahaman SIA & .712 & 1.404 \\
\hline
\end{tabular}

Sumber : Pengelolahan Data SPSS 
Dilihat pada tabel 3 dijelaskan bahwa masing-masing variabel independen memiliki nilai tolerance $>0.1$ dan nilai VIF $<10$, maka dapat disimpulkan bahwa antar variabel independen dalam penelitian ini tidak terjadi multikolinearitas.

Uji Heteroskedastisitas

Table 4

Hasil uji heteroskedastisitas

\begin{tabular}{lc}
\hline & Sig. \\
\hline Pengendalian Intern (X1) & .471 \\
Pemahaman SIA (X2) & .689 \\
\hline
\end{tabular}

Sumber: Pengelolahan Data SPSS

Dilihat pada tabel 4 dijelaskan bahwa variabel X1 memiliki nilai signifikansi .471 dan variabel X2 memiliki nilai signifikansi 689 yang artinya nilai signifikan tiap variabel independen $>0.05$ maka dapat disimpulkan bahwa tidak terdapat gejala heteroskedastisitas.

\section{Hasil dan PembahasanAnalisa Kuesioner}

Kuesioner yang dijalankan dalam penelitian ini sebanyak 53 Kuesioner pada karyawan Badan Keuangan dan Aset Daerah dan 53 kuesioner pada karyawan SKPD. Kuesioner yang dibagikan memiliki 16 pertanyaan mengenai pengendalian intern, 14 pertanyaan mengenai kualitas laporan keuangan dan 14 pertanyaan mengenai sistem informasi akuntansi. Berikut tabel descriptive statistic kuesioner yang dijalankan dan di jawab berdasarkan skala likert.

Tabel 5

Tabel deskriptif statistik

\begin{tabular}{lccc}
\hline Variabel & Rata-rata & Std. Dev & Jumlah \\
\hline Keefektifan & & & \\
Pengendalian Intern & 3.8349 & 1.09247 & 53 \\
Pemahaman SIA & 3.8127 & 1.10511 & 53 \\
Kualitas laporan & & & 53 \\
Keuangan & 3.9245 & .99782 & \\
\hline
\end{tabular}

Sumber: Pengolahan Data SPSS

Berdasarkan tabel 5 ditunjukkan bahwa rata-rata jawaban responden untuk variabel keefektifan pengendalian intern sebesar 3.8349, pemahaman sistem informasi akuntansi sebesar 3.8127 dan variabel kualitas laporan keuangan sebesar 3.9245 dengan jumlah responden yang menjawab 53 orang. Dengan arti keefektifan pengendalian intern dan pemahaman sistem informasi akuntansi pegawai di kantor Badan Keuangan dan Aset Daerah Provinsi Sulawesi Utara dapat digolongkan sudah baik berdasarkan rata-rata yang ada pada tabel 4.1. Selanjutnya berdasarkan ratarata, untuk kualitas laporan keuangan Pemerintah Daerah Provinsi Sulawesi Utara juga dapat digolongkan sudah baik 


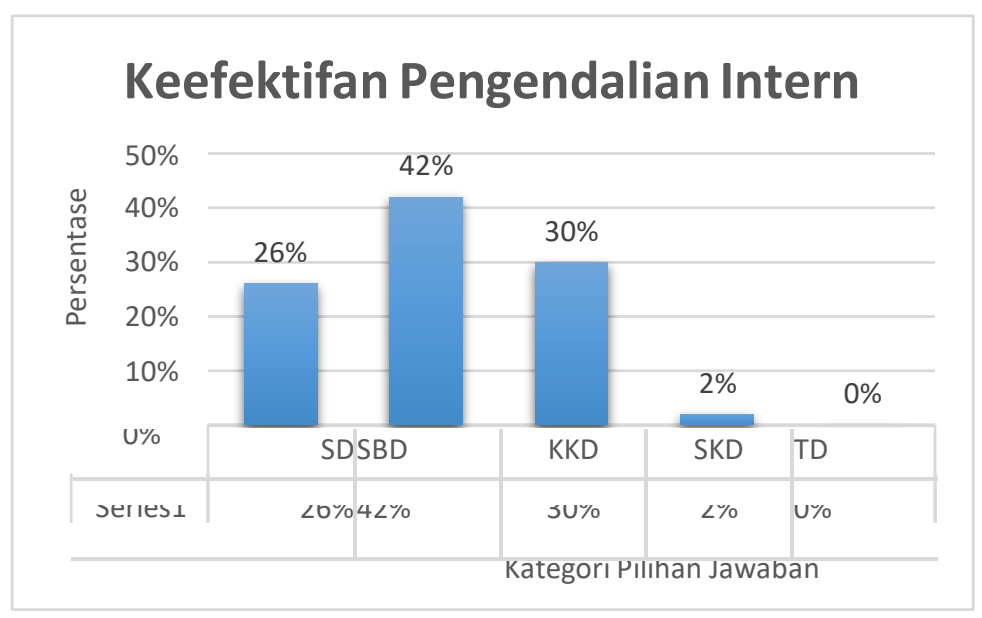

Gambar 1

Tabel Deskriptif Keefektifan Pengendalian Intern

Berdasarkan Gambar 1, sebanyak 42\% menjawab keefektifan pengendalian intern Badan Keuangan dan Aset Daerah "Sebagian Besar Diterapkan" (SBD), diikuti oleh 30\% responden yang menjawab bahwa keefektifan pengendalian intern Badan keuangan dan Aset Daerah "Kadangkadang diterapkan" (KKD), selanjutnya 26\% responden yang menjawab "Seluruhnya Diterapkan" (SD), dan hanya $2 \%$ responden yang menjawab keefektifan pengendalian intern Badan Keuangan dan Aset Daerah "Sebagian Kecil Diterapkan" (SKD), hal ini mengindikasikan bahwa ada perhatian khusus yang harus diberikan oleh Badan Keuangan dan Aset Daerah perihal keefektifanpengendalian intern yang belum sepenuhnya diterapkan

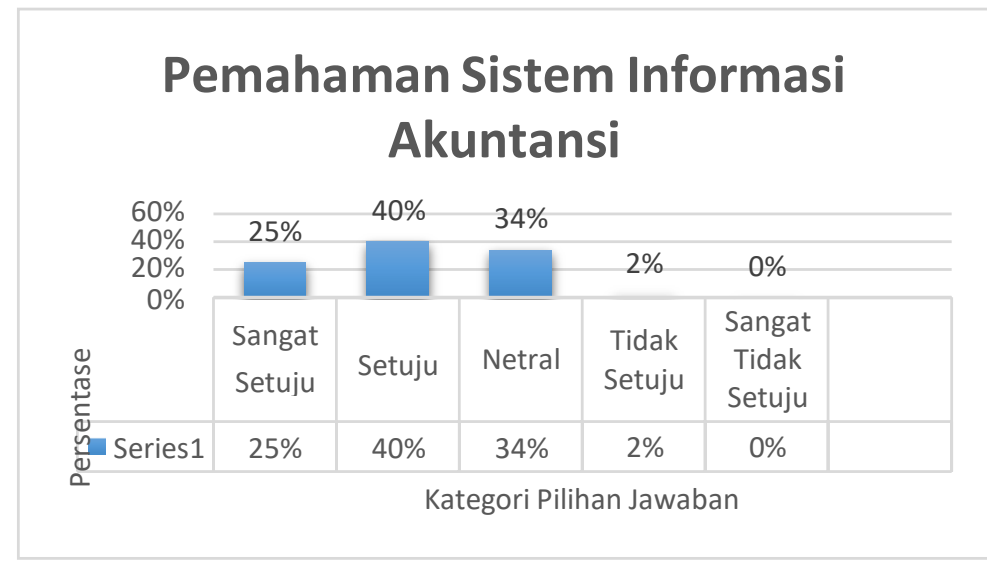

Gambar 2

Tabel Deskriptif Pemahaman Sistem Informasi Akuntansi

Gambar 2 menunjukan bahwa dalam menyusun laporan keuangan Badan Keuangan dan Aset Daerah 40\% responden menjawab "Setuju" (S) dengan pemahaman sistem informasi akuntansi, diikuti oleh 34\% responden yang menjawab "netral" (N) mengenai pemahaman sisteminformasi akuntansi, kemudian sebanyak 25\% responden menjawab "Sangat Setuju" (SS) denganpemahaman 
sistem informasi Badan Keuangan dan Aset Daerah, dan hanya 2\% yang menjawab "Tidak Setuju" (TS) mengenai sistem informasi akuntansi Badan Keuangan dan Aset Daerah, hal ini mengindikasikan bahwa ada perhatian khusus yang perlu diberikan oleh Badan Keuangan dan Aset Daerah perihal sistem informasi akuntansi yang belum sepenuhnya dipahami

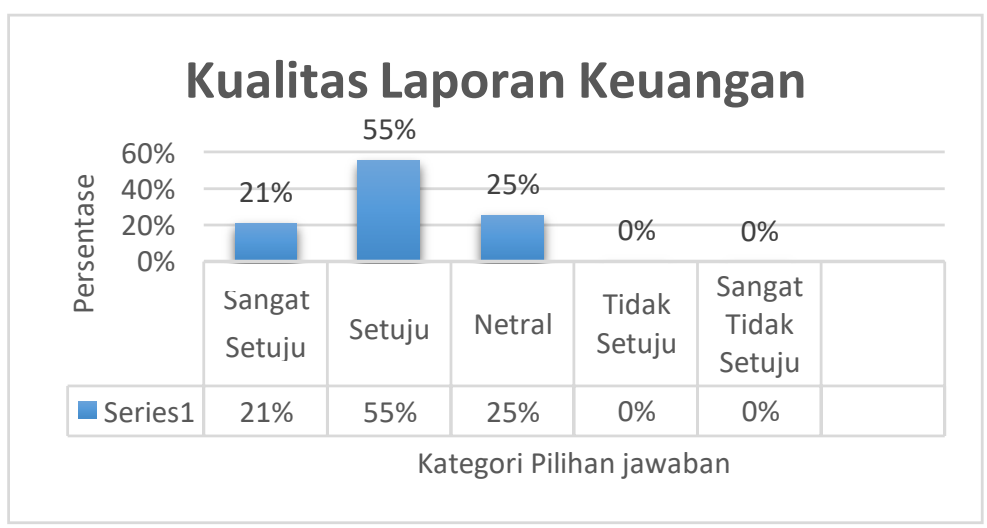

Gambar 3

Deskripsi responden karyawan bagian keuangan berdasarkan Gender

Berdasarkan gambar 3, sebanyak 55\% responden menjawab mereka "Setuju” bahwa laporan keuangan yang disajikan sudah berkualitas berdasarkan butir-butir pertanyaan yang ada dalam kuesioner, seperti contoh informasi dalam laporan ekuangan dapat digunakan untuk mengoreksi kepurusan pengguna di masa lalu sehingga dapat berguna dalam pengambilan keputusan. Kemudian sebanyak 25\% responden menjawab bahwa mereka "Netral" (N) laporan keuangan yang disajikan sudah berkualitas, dan diikuti oleh responden sebanyak 21\% menjawab"Sangat Setuju” (SS) laporan keuangan yang disajikan sudah berkualitas.

\section{Hasil Uji Hipotesis}

Tabel 6

Hasil uji t

\begin{tabular}{|c|c|c|c|c|}
\hline Model & $\begin{array}{l}\text { InstandardizeCoef } \\
\text { Beta }\end{array}$ & $\begin{array}{l}\text { Standardize } \\
\text { Coef. Beta }\end{array}$ & $\mathrm{t}$ & Sig \\
\hline (Constant) & 15.751 & .399 & 3.327 & .002 \\
\hline Keefektifan & & & & \\
\hline Pengendalian Intern & .302 & .399 & 3.709 & .001 \\
\hline Pemahaman SIA & .387 & .474 & 4.398 & .000 \\
\hline
\end{tabular}

Sumber : Pengolahan Data SPSS

Dari hasil uji linear berganda yang telah diolah dengan bantuan aplikasi SPSS, maka didapatkan hasil dari regresi linear berganda yang dapat dibentuk persamaan sebagai berikut: 
Kualitas Laporan Keuangan $=15.751+0,302 \mathrm{X} 1+0,387 \mathrm{X} 2+\mathrm{e}$

Keterangan :

$\mathrm{X} 1$ : Keefektifan pengendalian intern

$\mathrm{X} 2$ : Pemahaman sistem informasi akuntansi

Berdasarkan hasil pengujian tabel diatas, maka dapat diperoleh hasil dari hipotesis sebagaiberikut:

\section{H1 : Keefektifan Pengendalian Intern berpengaruh signifikan terhadap kualitas laporan keuangan}

Dari tabel 6 menunjukan bahwa variabel Keefektifan Pengendalian Intern memiliki p-value 0,001 artinya lebih kecil dari 0,05 oleh karena itu H1 diterima dengan arti keefektifan pengendalian intern memiliki pengaruh yang signifikan terhadap kualitas laporan keuangan Badan Keuangan Aset Daerah Provinsi Sulawesi Utara. Adapun nilai koefisien yang ditunjukan ialah nilai positif yang artinya semakin baik atau semakin besar keefektifan pengendalian intern maka semakin berkualitas pula suatu laporan keuangan.

Hasil uji hipotesa tersebut sejalan dengan penelitian yang dilakukan oleh Sari (2015), Mamuaja (2016) dan Hariadi (2010) yang memperoleh hasil keefektifan pengendalian intern memiliki pengaruh signifikan. Tujuan dirancangnya pengendalian intern adalah agar dapat diperoleh data yang dapat dipercaya serta meningkatkan kualitas laporan keuangan.

Selain itu, untuk mengurangi kegiatan atau sikap menyimpang atau kecurangan pada laporan keuangan perlu untuk meningkatkan pengendalian intern pemerintahan. Organisasi pemerintahan merupakan organisasi non profit dengan arti tidak mencari keuntungan tetapi hanya mengemukakan kepentingan masyarakat, walaupun begitu organisasi pemerintahan tetap memerlukan sistem pengendalian intern yang mengatur secara efektif dan efisien (Hariadi, Pengelolaan keuangan daerah, 2010).

\section{H2 : Pemahaman Sistem Informasi Akuntansi berpengaruh signifikan terhadap kualitas laporan keuangan}

Dari tabel 6 menunjukan bahwa variabel Pemahaman Sistem Informasi Akuntansi memiliki p-value 0,000 artinya lebih kecil dari 0,05 oleh karena itu H2 diterima dengan arti Pemahaman Sistem Informasi Akuntansi memiliki pengaruh yang signifikan terhadap kualitas laporan keuangan Badan Keuangan Aset Daerah Provinsi Sulawesi Utara. Adapun nilai koefisienyang ditunjukan ialah nilai positif yang artinya semakin baik pemahaman sistem informasi akuntansi pegawai pemerintahan maka semakin berkualitas pula suatu laporan keuangan. Dari hasil yang ditunjukan pada tabel 4.1, pemahaman sistem informasi akuntansi berpengaruh lebih tinggi dibandingkan variabel yang lain maka dapat disimpulakan bahwa pemahaman kualitas laporan keuangan akan lebih dipengaruhi oleh pemahaman sistem informasi akuntansi.

Hasil penelitian ini mendukung penelitian sebelumnya yang dilakukan oleh Romney dan Steinbert (2005), Muslih (2010) dan Herawati (2014) yang mengemukakan bahwa sistem informasi akuntansi memiliki pengaruh terhadap kualitas laporan keuangan.

Informasi pada perusahaan berhubungan dengan data input maupun output informasi yang 
dihasilkan dari sistem, dalam menunjang kinerja pengguna. Laudon dan Laudon (2007) mengemukakan sebuah organisasi memerlukan informasi yang sehat yang artinya sistem informasi yang bertujuan menghasilkan informasi keuangan ialah sistem informasi akuntansi. Yang menjadi kewajiban Pemerintah dalam penyusunan laporan keuangan ialah kesesuaian penyusunan dengan Sistem Akuntansi Keuangan Daerah yang sudah diatur oleh pemerintah daerah berpatokan pada SAP pada undang-undang yang bersifat mengikat semua pemerintah daerah agar bisa disimpulkanbahwa Pemahaman Sistem Informasi Akuntansi Keuangan yang baik berpengaruh terhadap kualitas laporan keuangan pemerintah.

Namun ada juga penelitian yang tidak sejalan dengan hasil penelitian ini, seperti hasil penelitian yang dilakukan oleh Erawati dan Abdulhadi (2018) yang membuktikan pemahaman sistem akuntansi keuangan daerah tidak mempengaruhi kualitas laporan keuangan.

Tabel 7

Hasil uji koefisien determinan

\begin{tabular}{llrrr}
\hline Model & R & R Square & $\begin{array}{l}\text { Adjusted } \\
\text { R Square }\end{array}$ & $\begin{array}{l}\text { Std. error } \\
\text { of The Estimated }\end{array}$ \\
\hline 1 & .766 & .587 & .570 & 6.465 \\
\hline
\end{tabular}

Sumber : Pengolahan Data SPSS

Berdasarkan tabel 7 hasil uji koefisien determinasi didapatkan nilai Adjusted $R$ Square sebesar 0,570 artinya besarnya pengaruh dari keefektifan pengendalian intern, pemahaman sistem informasi akuntansi terhadap kualitas laporan keuangan Badan Keuangan dan Aset Daerah sebesar $57 \%$, sisanya sebesar $43 \%$ dipengaruhi oleh faktor-faktor lain yang tidak diamati dalam penelitianini.

\section{Kesimpulan}

Dari penelitian yang telah dibahas pada bab sebelumnya, maka peneliti dapat mengambil kesimpulan yaitu dilihat dari tabel deskriptif dapat disimpulkan bahwa keefektifan pengendalian intern danpemahaman sistem informasi akuntansi dari pegawai Badan Keuangan dan Aset Daerah Provinsi Sulawesi Utara sudah baik maka memberikan kesimpulan juga bahwa penyusunankualitas laporan keuangan yang ada di kantor Pemerintah Daerah Provinsi Sulawesi Utara sudah baik. Keefektifan pengendalian intern memiliki pengaruh signifikan terhadap kualitas laporan keuangan Badan Keuangan dan Aset Daerah Provinsi Sulawesi Utara secara parsial, terlihat dari nilai $p$-value lebih kecil dari 0,05 yang berarti $\mathrm{H} 1$ dari penelitian ini diterima.Keefektifan pengendalian intern merupakan faktor yang kuat dalam peningkatan kualitas laporan keuangan. Pemahaman sistem informasi akuntansi memiliki pengaruh signifikan terhadap kualitas laporan keuangan Badan Keuangan dan Aset Daerah Provinsi Sulawesi Utara secara parsial, yang berarti pemahaman sistem informasi akuntansi merupakan faktor yang kuat dalam peningkatan kualitas laporan keuangan, terlihat dari nilai $p$-value lebih kecil dari 0,05 artinya $\mathrm{H} 2$ dalam penelitian ini diterima. Pengaruh Keefektifan pengendalian intern dan pemahaman sistem informasi akuntansi terhadap kualitas lapora keuangan Badan Keuangan dan Aset Daerah sebesar 57\% terlihatdari tabel hasil uji koefisien Determinan $\left(R^{2}\right)$. 


\section{Saran}

1. Bagi Pegawai Badan Keuangan Aset Daerah dan SKPD

Dari penelitian ini, Badan Keuangan dan Aset Daerah Provinsi Sulawesi Utara dapat mempertahankan serta meningkatkan hal-hal terkait keefektifan pengendalian intern, pemahaman sistem informasi akuntansi dan kualitas laporan keuangan. Kemudian, melalui penelitian ini dapat menjadi basis bagi Badan Keuangan untuk mengevaluasi kinerja pegawai dalam pelaksanaan pengendalian intern yang efektif, pemahaman sistem informasi akuntansi dan penilaian kualitas laporan keuangan yang dibuat,agar informasi yang disajikan dalam laporan keuangan akurat dan lengkap dapat menjadi dasaryang kuat dalam pengambilan keputusan.

\section{Bagi Peneliti}

Para peneliti selanjutnya yang akan mengkaji lebih lanjut dalam bidang yang sama dapat memperluas lagi ruang lingkup penelitian dengan memperluas populasi serta menambah sampel penelitian. Penelitian selanjutnya dapat menambah variabel atau aspek lain bukan hanya terbatas pada variabel terkait penelitian ini yang diduga memiliki pengaruh terhadap kualitas laporankeuangan pemerintah, misalnya pemanfaatan teknologi informasi dan lain sebagainya. 


\section{Daftar Pustaka}

Azhar, L. M., \& Susanto. (2001). Sistem informasi dan akuntansi I dan II. Bandung: Lembaga Informasi.

Badan Pemeriksa Keuangan Republik Indonesia. (2004). Retrieved from http://www.bpk.go.id/assets/files/storage/2013/12/file_storage_1386158654.pdf

Badan Pengawasan Keuangan dan Pembangunan. (2017). Retrieved from http://www.bpkp.go.id/public/upload/unit/sulut/files/LK_2017_Audited\%20BPKP\%20SUL UT.pdf

Darmawan, A. (2018). Analisis faktor-faktor yang mempengaruhi kualitas laporan keuangan pemerintah daerah. Yogyakarta, Indonesia.

Erawati, T., \& Abdulhadi, M. F. (2018). Pengaruh pemahaman sistem akuntansi keuangan daerah, kapasitas sumber daya manusia dan pemanfaatan teknologi informasi terhadap kualitas informasilaporan keuangan pemerintah daerah. Jurnal Akuntansi \& Manajemen Akmenika, 15(1).

Esya, F. P. (2008). Pengaruh kompetensi auditor dan pemahaman sistem informasi akuntansi terhadap kinerja auditor bea dan cukai di wilayah Jakarta. Medan, Sumatera Utara, Indonesia.

Gronlund, N. E., \& LInn, R. L. (1990). Measurement and evaluation in teaching. New York: Mcmillan Publishing Company.

Hariadi, P. (2010). Pengelolaan keuangan daerah. Jakarta: Salemba Empat.

Herawati, T. (2014). Pengaruh sistem pengendalian internal terhadap kualitas laporan keuangan (survei pada organisasi perangkat daerah Pemda Cianjur). Study \& Accounting Research, 114.

Ikatan Akuntan Indonesia. (2015). Standar Akuntansi Keuangan. Jakarta: Salemba Empat.

Ikatan Akuntansi Indonesia. (2009). Pernyataan Standar Akuntansi Keuangan (PSAK) No1 : Penyajian Laporan Keuangan. Jakarta: IAI.

Juwita, R. (2013). Pengaruh implementasi standard akuntansi pemerintahan dan sistem informasi akuntansi terhadap kualitas laporan keuangan. Trikonomika, 201-214.

Kementerian Keuangan. (2003). Retrieved from http://www.djpk.depkeu.go.id/attach/post-uu-no17- tahun-2003-tentang-keuangan-negara/UU-63-61-uu17_2003.htm

Laudon, K. C., \& Laudon, J. P. (2012). Management information systems - managing the digital firm. New York: Pearson Prentice Hall.

Mamuaja, B. (2016). Efektivitas penerapan sistem pengendalian intern terhadap kinerja instansi pemerintah di dinas pendapatan kota manado. EMBA, 4(1), 165-171.

Muslih, A. (2010). Pengaruh sistem informasi dan komunikasi terhadap kualitas laporan keuangan syariah. Computech \& Bisnis.

Octavianty, G. (2019). Implementasi sistem informasi akuntansi pada gita busana. Jurnal Ekonomi dan Bisnis.

Peraturan Pemerintah Republik Indonesia nomor 71 tahun 2010. (2010, Oktober 22). Lampiran II 
kerangkakonseptual akuntansi pemerintahan. Indonesia.

Romney, M. B., \& Steinbart, P. J. (2005). Sistem Informasi Akuntansi, Edisi 9 (diterjemahkan oleh Dewi Fitriasari dan Denny Arnos Kwary). Jakarta: Salemba Embat.

Saipullah, L. (2017). Pengaruh penggunaan sistem informasi akuntansi, kualitas sumber daya manusia, dansistem pengendalian internal terhadap kualitas laporan keuangan pemerintah daerah dengan lingkungan eksternal sebagai variabel moderating. Ekonomi dan Bisnis.

Sari, N. L. (2015). Pengaruh efektifitas sistem pengendalian internal, ketaatan aturan akuntansi, persepsi kesesuaian kompensasi dan implementasi good governance terhadap kecenderungan fraude. e-journal Universitas Pendidikan Ganesha, 3(1).

Sawyer, R. K. (2006). Explaining creativity: the science of human innovation. New York: Oxford UniversitasPress.

Sugiyono. (2012). Metode penelitian kuantitatif kualitatif dan R\&D. Bandung: Alfabeta.

Wilopo, D. (2006). Analisis faktor-faktor yang berpengaruh terhadap kecenderungan kecurangan akuntansi: studi pada perusahaan Publik dan badan usaha milik negara di Indonesia. Simposium Nasional Akuntansi 9.

Yuliani, S. (2010). Pengaruh Pemahaman Akuntansi, Pemanfaatan Sistem Informasi Akuntansi Keuangan Daerah dan Peran Internal Audit Terhadap Kualitas Laporan Keuangan Pemerintah Daerah (StudiEmpiris Pada Pemerintah Kota Banda Aceh). Jurnal Telaah dan Riset Akuntansi, 206-220. 